\title{
Coexisting ecosystem states in a tropical coastal lagoon under progressive eutrophication in the northern Cuban keys
}

\author{
Roberto González-De Zayas ${ }^{1}$, Martin Merino-Ibarra ${ }^{2}$, Patricia M. Valdespino-Castillo ${ }^{2}$, \\ Yunier Olivera ${ }^{1}$, Sergio F. Castillo-Sandoval ${ }^{2}$ \\ ${ }^{1}$ Centro de Investigaciones de Ecosistemas Costeros, Cayo Coco, Ciego de Ávila, Cuba. \\ (RG-Z) E-mail: cuba.robe@ gmail.com. ORCID iD: http://orcid.org/0000-0001-8035-8624 \\ (YO) E-mail: yunier@ ciec.cu. ORCID iD: http://orcid.org/0000-0002-2975-9470 \\ ${ }^{2}$ Unidad Académica de Ecología y Biodiversidad Acuática, Instituto de Ciencias del Mar y Limnología, Universidad \\ Nacional Autónoma de México, Ciudad Universitaria, Coyoacán, México, DF 04510, México. \\ (MM-I) (Corresponding author) E-mail: mmerino@cmarl.unam.mx. ORCID iD: http://orcid.org/0000-0002--6690-3101 \\ (PV-C) E-mail: pancronica@ gmail.com. ORCID iD: http://orcid.org/0000-0002-2998-4627 \\ (SC-S) E-mail: castillo@cmarl.unam.mx. ORCID Id: http://orcid.org/0000-0002-5934-8859
}

\begin{abstract}
Summary: Through a nested suite of methods here we contrast the coexistence of different ecosystem states in a tropical coastal lagoon, the Laguna Larga, with increasing eutrophication stress between 2007 and 2009. Water temperature averaged $27.4^{\circ} \mathrm{C}$ in the lagoon and showed a slight positive trend during the study period. Salinity averaged $35.0 \pm 6.2$, exhibiting high spatial and temporal variability, and also a slight positive trend in time. In contrast, dissolved oxygen showed a substantial decreasing trend $\left(-0.83 \mathrm{ml} \mathrm{L}^{-1} \mathrm{y}^{-1} ;-13.3 \% \mathrm{y}^{-1}\right)$ over the period, while nutrients increased dramatically, particularly total phosphorus $\left(2.6 \mu \mathrm{M} \mathrm{y}^{-1}\right)$, in both cases sustaining the progression of eutrophication in the lagoon during the three years we sampled. The Karydis nutrient load-based trophic index showed that the lagoon has a spatial pattern of increasing eutrophication from the sea and the outer sector (oligotrophic-mesotrophic) to the central (mesotrophic) and the inner sector (mesotrophic-eutrophic). Two ecosystem states were found within the lagoon. In the outer oligotrophic sector, the dominant primary producers were macroalgae, seagrasses and benthic diatoms, while mollusc assemblages were highly diverse. In the inner and central sectors (where trophic status increased toward the inner lagoon) a phytoplankton-dominated ecosystem was found where mollusc assemblages are less diverse. In spite of the progression of eutrophication in the lagoon, these two different ecosystems coexisted and remained unchanged during the study period. Apparently, the effect of water residence time, which increases dramatically toward the inner lagoon, dominated over that of nutrient loadings, which is relatively more homogeneously distributed along the lagoon. Therefore, we consider that actions that reduce the water residence time are likely the most effective management options for this and other similarly choked lagoons.
\end{abstract}

Keywords: ecosystem; nutrients; dissolved oxygen; eutrophication; Laguna Larga; Cayo Coco; Cuba.

Estados ecosistémicos coexistentes en una laguna costera tropical bajo eutrofización creciente en la cayería norte de Cuba

Resumen: Mediante la conjunción de una diversidad de métodos y observaciones, se contrasta la coexistencia de diferentes estados ecosistémicos en Laguna Larga, una laguna costera tropical sometida a una eutrofización creciente entre 2007 y 2009. La temperatura media en la laguna fue de $27.4^{\circ} \mathrm{C}$ y mostró una ligera tendencia positiva en este periodo. La salinidad mostró alta variabilidad espacial y temporal alrededor de una media de $35.0 \pm 6.2$ y también tuvo una tendencia temporal positiva. En contraste, el oxígeno disuelto mostró una sustancial tendencia negativa $\left(-0.83 \mathrm{ml} \mathrm{L}^{-1} \mathrm{y}^{-1} ;-13.3 \% \mathrm{y}^{-1}\right)$ en el mismo periodo, al tiempo que los nutrientes se incrementaron drásticamente, en particular el fósforo total, a una tasa de $2.6 \mu \mathrm{M} \mathrm{y}^{-1}$, respaldando ambas tendencias el incremento de la eutrofización a lo largo de los tres años observados. El índice trófico de Karydis, basado en las cargas de nutrientes, mostró un patrón espacial de incremento de la eutrofización desde el mar hacia el sector exterior (oligotrófico-mesotrófico), el sector central (mesotrófico) y el sector interior (mesotrófico-eutrófico). Se identificaron dos estados ecosistémicos dentro de la laguna. En el oligotrófico sector exterior, los productores primarios dominantes fueron macroalgas, pastos marinos y diatomeas bénticas, en tanto que las asociaciones de moluscos fueron altamente diversas. En los sectores central e interior (incrementándose el estatus trófico hacia este último), se encontró un estado ecosistémico dominado por el fitoplancton y en el que las asociaciones de moluscos son menos diversas. A pesar del incremento de la eutrofización, estos dos ecosistemas distintos coexistieron y permanecieron sin cambios durante el periodo estudiado. En Laguna Larga, el efecto del tiempo de residencia del agua, que se incrementa dramáticamente hacia el interior de la laguna, domina aparentemente sobre el de la carga externa de nutrientes, que está distribuida de manera relativamente más homogénea a lo largo de la laguna. Por ello, consideramos que las acciones dirigidas a disminuir el tiempo de residencia del agua son probablemente las más efectivas en esta laguna y otras similarmente aisladas.

Palabras clave: ecosistema; nutrientes; oxígeno disuelto; eutrofización; Laguna Larga; Cayo Coco; Cuba. 
Citation/Como citar este artículo: González-De Zayas R., Merino-Ibarra M., Valdespino-Castillo P.M., Olivera Y., Castillo-Sandoval S.F. 2018. Coexisting ecosystem states in a tropical coastal lagoon under progressive eutrophication in the northern Cuban keys. Sci. Mar. 82(3): 139-146. https://doi.org/10.3989/scimar.04682.22A

Editor: X.A. Alvarez-Salgado.

Received: June 27, 2017. Accepted: September 21, 2018. Published: September 27, 2018.

Copyright: ( 12018 CSIC. This is an open-access article distributed under the terms of the Creative Commons Attribution 4.0 International (CC BY 4.0) License.

\section{INTRODUCTION}

Aquatic ecosystems are affected by multiple anthropogenic perturbations, particularly increasing nutrient loadings (Cropp and Gabric 2002). In order to assess these impacts, a central issue in the management of transitional and coastal ecosystems has been the identification of key signals that indicate the ecosystem's ecological status (Orfanidis et al. 2003). Water quality and trophic status assessment of coastal and marine waters are often used to evaluate their condition for a better control of the coastal and marine resources (Paerl 2006).

In coastal waters, the bidirectional flux of materials and energy between land and water, as well as aquatic life and human activities, are closely related. In this region, complex interactions between terrestrial variables (nutrients and sediments inputs) and oceanic factors (tides and currents) take place (Morales-Ojeda et al. 2010). Regarding the ecosystems as dynamic open systems with multiple equilibrium states (Holling 1973) further strengthens the need for ecological assessment, because the restoration of desired states may require drastic and expensive intervention (Maler 2000).

Coastal lagoons are intrinsically unstable, mainly due to their location along the coastline and inherent morphodynamics (Viaroli et al. 2008). They have shallow waters, only a few metres deep, and salinity that varies from fresh water to hypersaline depending on their water balance (Kjerfve 1994). According to Viaroli et al. (2008), coastal lagoons are transitional ecosystems in which natural and human stressors can induce a wide variability, leading to substantial chang- es in the whole system and associated communities. Within certain thresholds, these transitional conditions could allow multiple alternative stable states to coexist and persist over several generations after the cessation of perturbations.

In coastal lagoons, eutrophication processes have been represented as a transition of alternative states, from pristine seagrass meadows to macroalgal or phytoplankton communities (Schramm 1999, Orfanidis et al. 2003, Dahlgren and Kautsky 2004). Previous studies showed that primary producers generally respond to increasing nutrient concentrations in shallow coastal waters in a sequence of successive phases of increasing eutrophication (Schramm and Nienhuis 1996). The aim of this study was to assess the progression of natural and human stressors that drive eutrophication in a tropical coastal lagoon (Laguna Larga, off the northeastern Cuban keys) where we found the coexistence of several ecosystem stable states.

The Laguna Larga is a tropical coastal lagoon located $\left(22^{\circ} 32^{\prime} \mathrm{N}, 78^{\circ} 22^{\prime} \mathrm{W}\right)$ in the northern Cuban keys (Fig. 1) that has been extensively altered by the construction of four large hotels along its basin and on the lagoon itself. The construction has led to filling of the lagoon and compaction of soil, dumping of rubbish and sewage, road construction and dredging and vegetation clearance at some points (González-De Zayas 2012). Due to this invasive human use of the lagoon area, 25\% of the lagoon's original surface was refilled, while red mangrove (Rhizophora mangle) still occupies $60 \%$ of it. Because of this, the lagoon has very limited water exchange with the adjacent coastal sea (González-De Zayas et al. 2013), to which it is connected only through

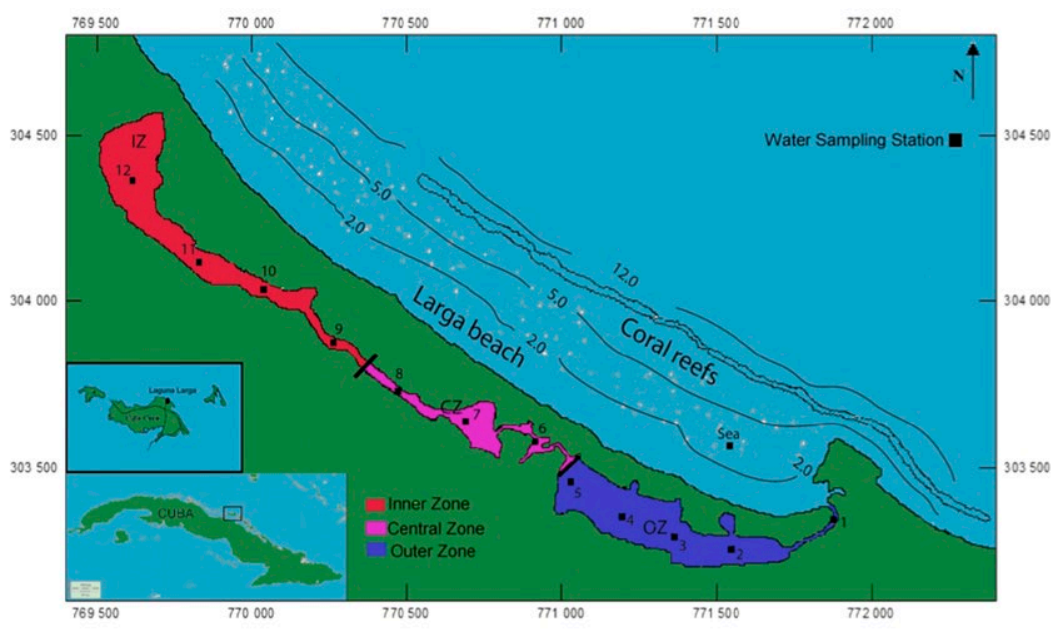

Fig. 1. - Location of the Laguna Larga, lagoon sectors and sampling sites in Cayo Coco, northeastern Cuban keys. 
a narrow channel (8-15 m wide) of variable depth (0.5$2 \mathrm{~m})$. Three main sectors form the lagoon: the outer (eastern), central (middle), and inner (western) sector, between which communication is also restricted to narrow channels fringed by mangroves. The bottom of the lagoon is irregular and very shallow in the central (0.3-0.5 m, stations 6, 7, 8, Fig. 1) and outer (0.5-0.8 m, stations 2, 3, 4, 5, Fig. 1) sectors. Only in the inner sector (1.0-1.2 m, stations 10, 11, 12, Fig. 1) does its depth reach $>1.0 \mathrm{~m}$, because it was dredged there (ExpósitoDíaz et al. 2001). Tides have very small amplitude in the region (cf. González-De Zayas et al. 2013 for more details on the regional physical setting).

Human impact on the system stems from international tourism (more than 50000 visitors per year), the main economic activity in the area, because the hotels and other facilities discharge their sewage directly or indirectly into the lagoon (González-De Zayas 2012). One of the hotels, the Tryp, has even built its main lobby on top of the lagoon (at station 9, Fig. 1), restricting water flow considerably at this point, where it also discharges its sewage. In an attempt to alleviate the eutrophication of the lagoon, the hotel built artificial fountains at this point to which groundwater was pumped until 2007 (González-De Zayas 2012). Because of all these nutrient inputs, the lagoon is considered eutrophic, and it exports nitrogen and phosphorus to the sea (González-De Zayas et al. 2013).

In terms of primary producers, there is a contrast between the dominance of phytoplankton in the central and inner sectors and the presence of marine phanerogams (Ruppia maritima, Halodule wrightii and Thalassia testudinum) in the outer sector (GuimaraisBermejo and González-De Zayas 2011). Similarly, studies on the taxonomic and functional diversity of mollusc assemblages have shown major differences between these sectors (Olivera 2014). In this study we pool together all these pieces of information to assess the trophic differences between the sectors in order to identify the time trends related to eutrophication effects and the resilience of the ecosystem states found in the lagoon.

\section{MATERIALS AND METHODS}

Bimonthly samplings were carried out between 2007 and 2009 over a sampling network evenly distributed in the three sectors of the lagoon, in the adjacent coastal sea outside the lagoon (Fig. 1) and in the main water inputs, following González-De Zayas (2012). Temperature and salinity were determined in situ using a WLW digital thermo-salinometer. Dissolved oxygen (DO) was determined in triplicate by the Winkler method. Samples for nutrients (dissolved inorganic nitrogen $\left(\mathrm{DIN}=\mathrm{NH}_{4}{ }^{+}+\mathrm{NO}_{2}^{-}+\mathrm{NO}_{3}{ }^{-}\right.$) and soluble reactive phosphorus (SRP)) were immediately filtered through Millipore filters of $0.22 \mu \mathrm{m}$ and fixed with chloroform. Filtered samples were frozen until analysis, together with unfiltered samples for total nitrogen (TN) and phosphorus (TP). Dissolved nutrients were analyzed with a Skalar San Plus segmented-flow autoanalyzer using the standard methods adapted by
Grasshoff et al. (1983) and the circuits suggested by Kirkwood (1994). Unfiltered samples for the analyses of TN) and TP were held in polypropylene containers and analysed as nitrate and SRP after high temperature $\left(120^{\circ} \mathrm{C}\right)$ oxidation with persulfate in an autoclave for 30 minutes, following Valderrama (1981). Organic nitrogen and organic phosphorus were calculated by subtraction (see González-De Zayas et al. 2013 for details). Nutrient loads were assessed following González-De Zayas (2012).

An affinity matrix among sampling sites was created using the Euclidean distance, considering all the physicochemical variables; then a hierarchical cluster was created, applying UPGMA as an agglomerative strategy. A trophic index (TI) derived from DIN and SRP was calculated, as proposed by Karydis et al. (1983) to account for each nutrient's loading to the area by:

$$
\mathrm{TI}=\frac{\mathrm{C}}{\mathrm{C}-\log \mathrm{X}}-\log \mathrm{A}
$$

where $\mathrm{C}$ is the logarithm of the total annual nutrient load, $\mathrm{X}$ is the nutrient concentration at each station and $\mathrm{A}$ is the number of stations. TI (dimensionless) generates a continuous evaluation of eutrophication where the scale is oligotrophic $<3$, mesotrophic between 3 and 5 , and eutrophic $>5$.

\section{RESULTS}

Water temperature in our study of Laguna Larga averaged $27.4^{\circ} \mathrm{C}$, and clearly followed a seasonal pattern (Fig. 2). Although temperature exhibited a slight positive trend in time, it was not significant $(\mathrm{p}=0.4262)$, and ANOVA also showed no significant differences between sampled years, likely because of the high seasonal variability. On average, salinity was $\sim$ marine (35.0), but it had individual values that ranged widely (8.0-64.8). The highest salinity variability occurred in the lagoon's central sector (31.4-64.8), where a maximum occurred at the end of the dry season (April) of 2009, and in the inner sector (8.0-48.0). Despite the volumes of sewage and freshwater discharged to the lagoon (e.g. $137 \mathrm{~m}^{3} \mathrm{~d}^{-1}$ in 2007 and $180 \mathrm{~m}^{3} \mathrm{~d}^{-1}$ in 2008; González-De Zayas et al. 2013), salinity in the outer sector (34.2-37.6) remained comparable to that of the adjacent sea (36.0-38.0) (Fig. 2). Among the annual means, differences were significant $(\mathrm{p}<0.01)$ between 2007 and both 2008 and 2009.

Mean DO concentration averaged $4.8 \mathrm{ml} \mathrm{L}^{-1}$ at the lagoon during the study period, but also exhibited high variability among stations, ranging from very high concentrations $\left(>10.0 \mathrm{ml} \mathrm{L}^{-1}\right)$ observed at times in shallow vegetated areas to hypoxic conditions often found in the central sector (mainly stations 8, 7 and 6) and anoxic conditions, which occurred only at station 9 but in nearly half of the samplings. For the lagoon as a whole, DO clearly decreased over time from 2007 to 2009 (Fig. 2) at a considerable rate $\left(-0.84 \mathrm{ml} \mathrm{L}^{-1} \mathrm{y}^{-1}\right)$, which overrode spatial and seasonal variability in the lagoon. However, likely due to the high variability of the DO data, this impressive trend was not statistically 
A Mean temperature at Laguna Larga between 2007 and 2009

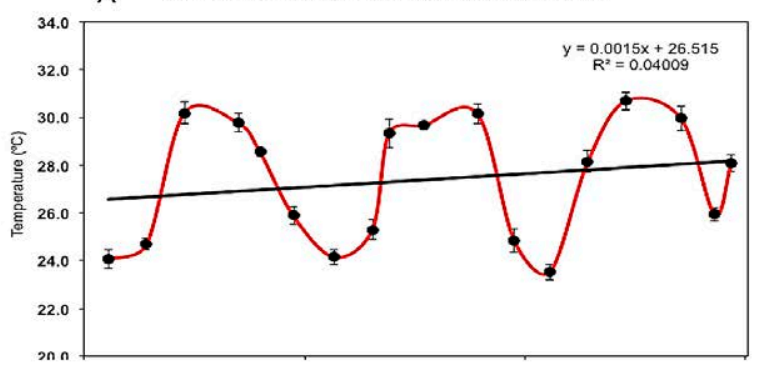

B Mean salinity at Laguna Larga between 2007 and 2009


Fig. 2. - Temporal evolution of mean temperature (A), mean salinity (B) and mean dissolved oxygen (C) at the Laguna Larga between 2007 and 2009. Error bars indicate standard errors. Trend line represents the included linear regression.

significant $(\mathrm{p}=0.1024)$. Because temperature and salinity influence the solubility of DO (Weiss 1970), we calculated the $\%$ of saturation of DO for the temperature and salinity of the samples. Applying these data, we plotted those values over time (Fig. 2) and found a more significant $(\mathrm{p}=0.0649)$ decreasing trend in the saturation of oxygen $\left(-13.3 \% \mathrm{y}^{-1}\right)$

$\mathrm{TN}$ was high, averaging $161.7 \pm 132.0 \mu \mathrm{M}$ in the lagoon during the study period, and showed an overall significant $(\mathrm{p}=0.0252)$ increasing temporal trend (Fig. 3 ), although a relative decrease occurred during 2008 . Organic nitrogen averaged $142.0 \pm 124.3 \mu \mathrm{M}$ in the lagoon, accounting for nearly $90 \%$ of TN. DIN averaged $19.8 \mu \mathrm{M}$ in the lagoon during the study period, and also showed an increasing trend, from 15.0 $\mu \mathrm{M}$ in 2007 and $18.8 \mu \mathrm{M}$ in 2008 to $25.29 \mu \mathrm{M}$ in 2009 . Ammonia was dominant ( $>50 \%$ of DIN), followed by $\mathrm{NO}_{3}^{-}(19-40 \%)$ and $\mathrm{NO}_{2}^{-}(<10 \%)$. Maximum concentrations of $\mathrm{NH}_{4}{ }^{+}$ $(439.05 \mu \mathrm{M})$ and $\mathrm{NO}_{2}{ }^{-}(22.42 \mu \mathrm{M})$ were found in December 2009.

TP averaged $4.6 \pm 4.5 \mu \mathrm{M}$ for the whole sampling period, and $90 \%$ of it was also organic. Temporally, TP
A Mean TN ( $\mu$ M) at Laguna Larga between 2007 and 2009

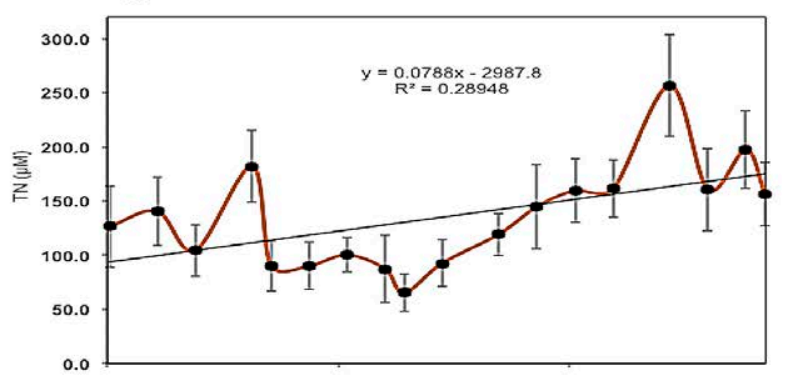

B Mean TP ( $\mu$ M) at Laguna Larga between 2007 and 2009

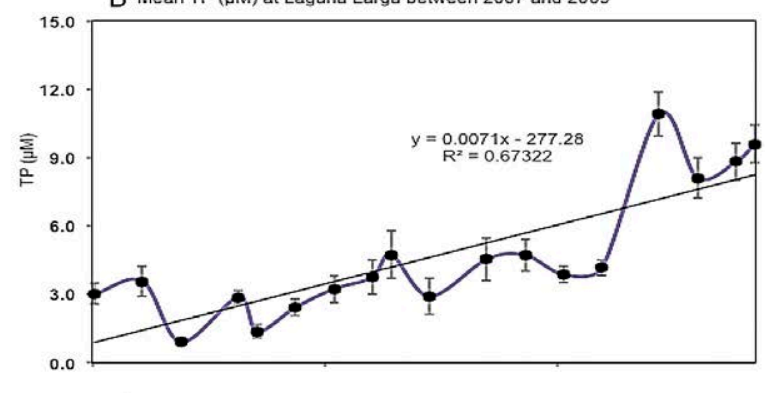

C Mean TN:TP at Laguna Larga between 2007 and 2009



Fig. 3. - Temporal evolution of mean total nitrogen (A), total phosphorus (B) and TN:TP ratio (C) at Laguna Larga between 2007 and 2009. Error bars indicate standard errors. Trend line represents the included linear regression.

showed an even stronger trend than TN (Fig. 3), significantly $(\mathrm{p}<0.0001)$ increasing from a mean concentration of $2.5 \mu \mathrm{M}$ in 2007 to $8.6 \mu \mathrm{M}$ in 2009 . Overall, TP increased in the lagoon by an impressively high rate of $2.6 \mu \mathrm{M} \mathrm{y}^{-1}$ during the study period. SRP also showed an increasing time trend, with higher concentrations in $2009(1.00 \pm 1.99 \mu \mathrm{M})$ than in $2007(0.09 \pm 0.1 \mu \mathrm{M})$ and $2008(0.52 \pm 0.66 \mu \mathrm{M})$. The Redfield ratio (overall mean TN/TP 39.4) pointed to phosphorus as the potentially limiting nutrient in the lagoon, although it also showed a significant $(\mathrm{p}=0.0012)$ decreasing trend throughout the three years sampled (Fig. 3).

Nutrient loading rates varied among the lagoon sectors and during the study period (Table 1). The SRP loading was generally higher in the outer sector (mean $\left.1.14 \mathrm{~g} \mathrm{~m}^{-2} \mathrm{y}^{-1}\right)$, with the highest level in 2008 (2.35 $\left.\mathrm{g} \mathrm{m}^{-2} \mathrm{y}^{-1}\right)$. For the whole lagoon, SRP annual loading ranged from 0.84 to $2.55 \mathrm{~g} \mathrm{~m}^{-2} \mathrm{y}^{-1}$, and was also higher in 2008. DIN loading ranged from 6.10 to $14.76 \mathrm{~g} \mathrm{~m}^{-2}$ $\mathrm{y}^{-1}$ and showed a different pattern; although it was high in the outer sector, DIN loading peaked in the inner sector in $2007\left(8.65 \mathrm{~g} \mathrm{~m}^{-2} \mathrm{y}^{-1}\right)$ and then decreased in 
Table 1. - Mean depth (m), soluble reactive phosphorus (SRP) loading, dissolved inorganic nitrogen (DIN) loading, the proportion between loadings (DIN:SRP), the residence time of water (RT) and main primary producers for each sector of the Laguna Larga and the whole ecosystem between 2007 and 2009. IS, lagoon's inner sector; CS, central sector; OS, outer sector; Phy, phytoplankton; Pha, phanerogams; Ma,

\begin{tabular}{|c|c|c|c|c|c|c|c|}
\hline Year & Sector & Mean depth (m) & $\operatorname{SRP}\left(\mathrm{g} \mathrm{m}^{-2} \mathrm{y}^{-1}\right)$ & DIN $\left(\mathrm{g} \mathrm{m}^{-2} \mathrm{y}^{-1}\right)$ & DIN:SRP (molar) & $\mathrm{RT}(\mathrm{d})$ & Primary producers \\
\hline \multirow[t]{4}{*}{2007} & OS & 0.7 & 0.51 & 5.26 & 22.8 & 1 & $\mathrm{Phy}+\mathrm{Pha}+\mathrm{Ma}$ \\
\hline & $\mathrm{CS}$ & 0.4 & 0.16 & 0.84 & 11.6 & 4 & Phy \\
\hline & IS & 1.1 & 0.30 & 8.65 & 63.8 & 34 & Phy \\
\hline & TOTAL & 0.73 & 0.98 & 14.76 & 33.3 & - & - \\
\hline \multirow[t]{4}{*}{2008} & OS & 0.7 & 2.35 & 5.19 & 4.9 & 9 & $\mathrm{Phy}+\mathrm{Pha}+\mathrm{Ma}$ \\
\hline & $\mathrm{CS}$ & 0.4 & 0.10 & 0.59 & 13.1 & 15 & Phy \\
\hline & IS & 1.1 & 0.09 & 2.85 & 70.1 & 251 & Phy \\
\hline & TOTAL & 0.73 & 2.55 & 8.63 & 7.5 & - & - \\
\hline \multirow[t]{4}{*}{2009} & OS & 0.7 & 0.58 & 2.24 & 8.6 & 1 & $\mathrm{Phy}+\mathrm{Pha}+\mathrm{Ma}$ \\
\hline & CS & 0.4 & 0.21 & 1.11 & 11.7 & 3 & Phy \\
\hline & IS & 1.1 & 0.05 & 2.76 & 122.2 & 84 & Phy \\
\hline & TOTAL & 0.73 & 0.84 & 6.10 & 16.1 & - & - \\
\hline
\end{tabular}

2008 , both there and in the lagoon as a whole. Table 1 shows these results, together with residence times (from González-De Zayas 2012) and primary producers (as identified by Guimarais-Bermejo and GonzálezDe Zayas 2011) in each sector of the lagoon during the sampling period.

Laguna Larga's sampling sites were clustered using all the physicochemical parameters measured (Fig. 4). Sites 1-5 and the adjacent coastal sea site grouped together. These stations are all within the outer sector of the lagoon, where water exchanges with the adjacent ocean take place. Another cluster was formed by sites 6,7 and 8, all of them located in the central sector of Laguna Larga, which has a restricted water exchange with the eastern part and the ocean. Another cluster, not too separated from this one, grouped sites 10, 11 and 12, at the innermost part of the coastal lagoon, where water exchange is very restricted and there are many nutrient inputs. Finally, the analysis set station 9 aside from the rest of the sites in the lagoon. Although hydrologically grouped in the inner sector (GonzálezDe Zayas 2012, González-De Zayas et al. 2013), the direct sewage discharge it receives from the Tryp Hotel likely sets it apart because of the extraordinary nutrient inputs and low oxygen found at this site.

The Karydis TI calculated with DIN and SRP showed a pattern of increasing eutrophication from the sea, through the outer and central sectors, to the

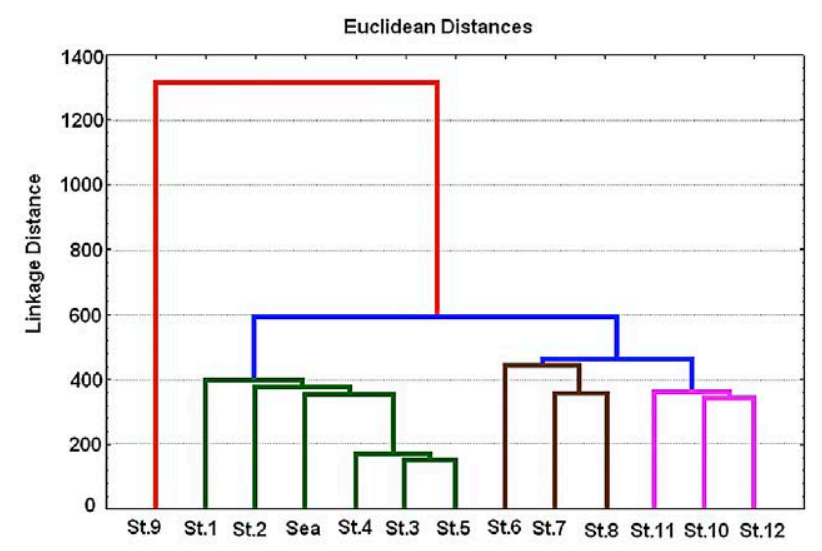

Fig. 4. - Laguna Larga sampling site clusters considering all the physicochemical parameters measured between 2007 and 2009. inner sector (Fig. 5). TI for DIN indicated oligotrophic conditions in the sea ( $\mathrm{TI}=2.7)$, mesotrophic conditions ( $\mathrm{TI}=3.6$ and 4.1 , respectively) in the outer and central sectors, and eutrophic conditions $(\mathrm{TI}=5.8)$ in the inner

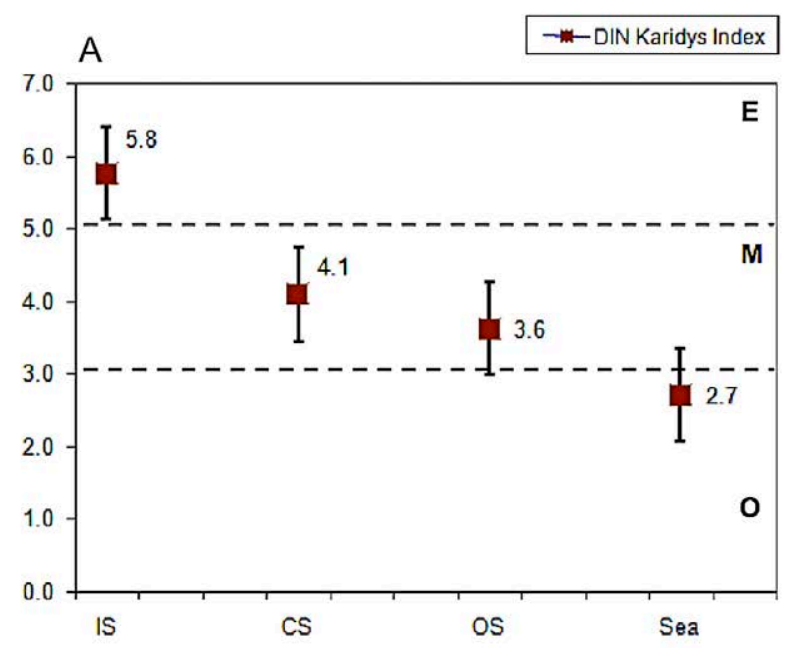

B

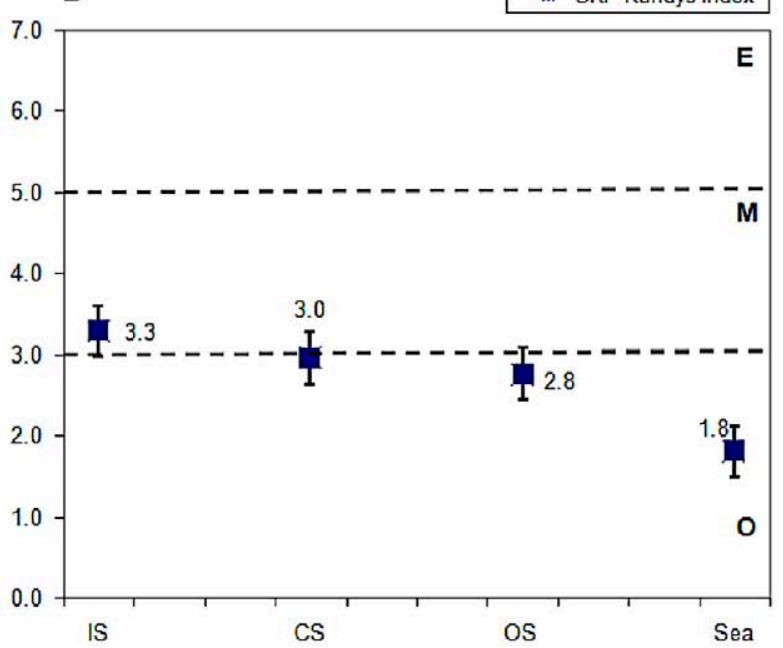

Fig. 5. - Trophic index mean for (A) dissolved inorganic nitrogen (DIN) and (B) soluble reactive phosphorus (SRP) for each of the sectors of Laguna Larga from 2007 to 2009, calculated following Karydis et al. 1983. Error bars indicate standard errors. Sea, site at the ocean; OS, lagoon's outer sector; CS, central sector; IS, inner sector; E, eutrophic state; M, mesotrophic; O, oligotrophic. 
sectors. TI for SRP also indicated an oligotrophic state ( $\mathrm{TI}=1.8$ and 2.8, respectively) for the sea and outer sector, while it assigned mesotrophic states to the central and inner sectors ( $\mathrm{TI}=3.0$ and 3.3, respectively).

\section{DISCUSSION}

THE invasive human use of the Laguna Larga has caused multiple alterations to its morphology and bathymetry that have furthered reduced its naturally low circulation, characteristic of tropical choked lagoons (Kjerfve 1986). This situation probably conditions most of its hydrological and biogeochemical processes. For example, the hydrologic circulation of the central sector of the lagoon was totally altered by its artificial closure, which has in turn caused changes in the distribution of salinity and dissolved oxygen (González-De Zayas 2012, González-De Zayas et al. 2013). Salinity has important implications in the management of coastal ecosystems, as it is an indicator of the relative proportion of marine and freshwater sources at each location (Herrera-Silveira 2006). Aquatic systems with restricted circulation and limited exchange with the adjacent sea, and where evaporation exceeds precipitation, exhibit an increasing salinity gradient from the mouth of the system to inner areas, which is reduced or reversed during the rainy season (González et al. 1992, Camacho-Ibar et al. 2003, Tapia-González et al. 2008). By contrast, salinity in the inner sector of the Laguna Larga was no higher than in the adjacent sea, revealing the influence of freshwater inputs from groundwater, rainfall, runoff and wastewater (González-De Zayas et al. 2013). A similar pattern was observed by Chagas and Suzuki (2005), who found that the typical increasing salinity gradient from outer to inner areas of coastal lagoons may even reverse during the rainy season. Variable salinity patterns have also been found in other tropical lagoon systems with low hydrologic circulation and limited connection to the sea. For instance, in the Nichupté and Dzilam lagoons, Mexico, Merino et al. (1990) and Herrera-Silveira (2006) found simultaneous oligohaline $(<5)$ and hyperhaline conditions $(>40)$ in portions of the innermost areas due to isolation and freshwater input, while the sectors connected to the sea showed no significant fluctuations of this parameter.

Dissolved oxygen in the lagoon showed a worrying negative trend during the study period, with a decrease of almost one $\mathrm{ml} \mathrm{L}^{-1}$ each year, equivalent to a $>13 \%$ decrease relative to saturation per year. This trend is consistent with a progression of eutrophication of the system, likely as a result of the combined anthropogenic impacts on the morphology, the increase in water residence time and the increase in nutrient inputs. Oxygen decrease is related to an increase in the occurrence of hypoxic and anoxic conditions in the lagoon (González-De Zayas 2012). Hypoxic conditions occurred mainly in the central sector, and anoxic conditions were observed at station 9, but increased their frequency from $30 \%$ of the sampling dates in 2007 to over $60 \%$ in 2009 . This is likely the result of the high discharge of sewage from the Hotel Tryp lobby (approximately $150 \mathrm{~m}^{3} \mathrm{~d}^{-1}$ ) to site 9 relative to the small volume of this very shallow sector of the lagoon. Hypoxia and anoxia have also been found in other shallow coastal lagoons due to the peaks in sewage discharge (Hernández-Romero et al. 2004). Although station 9 was grouped as part of the inner sector when its temperature and salinity were considered (González-De Zayas 2012, González-De Zayas et al. 2013), it is clear that the direct sewage discharge it receives from the Tryp Hotel clearly sets it apart in ecological terms, as the clustering used here reveals (Fig. 4), when both nutrient and oxygen are considered.

The anoxic conditions found at station 9 probably affect the plankton and benthic communities there, as has been found in other coastal eutrophic ecosystems (Ciglenečki et al. 2015). In fact, studies on mollusc assemblages in the lagoon have shown a decrease in the taxonomic and functional diversity of these assemblages near this area (Olivera 2014). However, anoxia was only observed very near the sewage discharge (station 9), likely because the shallowness of the lagoon facilitates the occurrence of re-aeration, as has been verified to occur in deeper systems (Wang et al. 2017). Nevertheless, the prevalence of hypoxic conditions in the inner and central sectors of the lagoon is likely also a consequence of the high residence time of water in the inner half of the lagoon. While the outer sector is fully washed by the tides generally within one day, the water exchange in the inner sector is much slower (of the order of months, Table 1) and variable, depending on the intensity of rainfall. Between December 2007 and February 2008, during a relatively dry period, the water residence time in the inner sector rose to 1187 days (González-De Zayas et al. 2013).

TN and TP concentrations in the lagoon were consistent with the oxygen patterns and trends observed, showing coupled inverse behaviours in their patterns and trends. Both nutrients showed significant increases in time for the lagoon as a whole, while DO and oxygen saturation decreased (Figs 2C, 3A and B). At a shorter scale, their variations were also closely coupled. The maxima of both nutrients observed in July 2009 (256.5 $\mu \mathrm{M}$ for TN and $10.9 \mu \mathrm{M}$ for TP, Figs $3 \mathrm{~A}, \mathrm{~B}$ ) co-occurred with the minimum DO saturation values $(37.5-46.7 \%)$ reached in July-September 2009 (Fig. 2C), indicating the period of most critical eutrophication in the lagoon between 2007 and 2009.

The TN/TP ratio was high in the lagoon (overall mean $=39.4$ ) and remained above the Redfield ratio (Fig. 3C) during the two sampled years. If nutrients were limiting in the lagoon, this could be used to flag $\mathrm{P}$ as the potentially limiting nutrient in the lagoon. But since the lagoon is clearly eutrophic, it more likely means that the excess of $\mathrm{N}$ is higher than the excess of $\mathrm{P}$ in the lagoon. Comparing with the ratio of the nutrient loads (Table 1) leads us to suggest that, although the loads are highly variable among the sectors and years, overall the proportion of nutrients in the lagoon has been determined mainly by the loads it has received (overall mean ratio $=32.2$ ). This seems to hold also on the year-by-year scale, since 2007 was highest in both proportions and 2008 lowest both for the lagoon and the loads. 
Nutrient variations in the lagoon are likely coupled to variations in the loads the lagoon receives (GonzálezDe Zayas et al. 2013), but they are also modulated by the contrast in the residence time of water-and therefore intensity of water renewal-among its sectors (Table 1). As a result, nutrients exhibited an increasing concentration gradient from the inlet of the lagoon to the inner sector, as reflected in the Karydis TIs (Fig. 5). This pattern occurs despite the fact that the outer sector of Laguna Larga receives very high loading (particularly of P). The high water exchange with the adjacent sea likely contributes to the dilution and output of nutrients in this sector (González-De Zayas 2012).

These contrasting conditions are likely behind the coexistence of two ecosystem states within the lagoon, e.g. in terms of the kind of primary producers that dominate in each. In the outer sector of the lagoon, seagrasses, macroalgae and benthic diatoms are the main primary producers (Guimarais-Bermejo and González-De Zayas 2011). In the inner and central sectors, a phytoplankton-dominated state prevails, where the degraded water conditions favour cyanobacteria (González-De Zayas 2012). These two ecosystem states also differ significantly in their primary production. A very high productivity (average $4.32 \pm 3.59 \mathrm{~g}$ $\mathrm{C} \mathrm{m}^{-2} \mathrm{~d}^{-1}$ ) in the outer sector contrasts with the much lower productivity measured in the central and inner sectors $\left(0.71 \pm 0.41 \mathrm{~g} \mathrm{C} \mathrm{m}^{-2} \mathrm{~d}^{-1}\right.$, Guimarais-Bermejo and González-De Zayas 2011). These authors attribute this to the increasing degradation toward the inner sectors of the lagoon. Animal components of the communities also change between these two ecosystem states. Olivera (2014) found that the structure of mollusc assemblages changed toward the inside of the lagoon, becoming taxonomically and functionally less diverse than in the outer sector. Theoretically, stressful environmental conditions should act as a filter, allowing only a narrow spectrum of species to survive in the central and inner sectors of the lagoon (Olivera 2014).

The coexistence of these two ecosystem states in the lagoon is likely more related to the contrast of water residence times than to differences in nutrient loading between the sectors. Although Viaroli et al. (2008) state that tentative thresholds for DIN loading, which are assumed to control mainly the persistence of benthic phanerogams, have been identified, in our study no consistent relationships between primary producers and DIN loading were found (see Table 1). According to Viaroli et al. (2008), phanerogams are dominant below $10 \mathrm{~g} \mathrm{~m}^{-2} \mathrm{y}^{-1}$, whereas macroalgae are predominant between 10 and 50 $\mathrm{g} \mathrm{m}^{-2} \mathrm{y}^{-1}$ and phytoplankton above $50 \mathrm{~g} \mathrm{~m}^{-2} \mathrm{y}^{-1}$. Our measures show that primary producers seem to be more related to the residence time than to DIN loading. These results are consistent with experimental studies that have shown that the abundance and distribution of different primary producers are highly variable, and that simple predictive relationships cannot be used for very shallow coastal lagoons (Taylor et al. 1995, Nixon et al. 2001, Viaroli et al. 2008).

In the lagoon, in spite of the large SRP and DIN loadings that are found in the outer sector, a phanerogam-dominated stable state remains there, likely due to the very short water residence time and the high water exchange with the adjacent sea. On the other hand, lower SRP but higher DIN loading rates combined with large water residence times (from 34 to 251 days) in the central and inner sectors have led to the prevalence of a phytoplankton-dominated stable ecosystem there. The coexistence of different stable ecosystem states inside the lagoon in spite of the drastic progression of eutrophication sustains the importance of alternative attractors even in what would seem to be a transient system (Schröder et al. 2005).

Most of the factors affecting Laguna Larga are direct or indirect consequences of the tourism development of the region. As in other coastal lagoons, such as the Mar Menor in Spain (Garcia-Pintado et al. 2007), Nichupté in the Yucatan Peninsula (Merino et al. 1992) and Araruama in Brazil (Souza et al. 2003), tourism development that involves uncontrolled construction and interventions in nature without consultation with ecology experts has caused hydrological and chemical changes in these water bodies that are likely to increase, as tourism is one of the fastest-growing sectors in the world, and an indispensable economic activity in Cuba.

In terms of what can be done to mitigate alteration and to enhance the carrying capacity of the lagoon, it is important to bear in mind that our findings show that actions that facilitate water exchange and therefore decrease the water residence time within the lagoon are probably the most efficient intervention option. This alternative has proved effective in other similar systems. For example, in the National Park Mljet in Croatia, the widening of the Soline channel had a very positive impact: the disappearance of anoxia in the near-sediment waters of the most inner part of the system (Hrustić and Bobanović-Ćolić 2017). Because of the choked nature of the lagoon, the Cuban government is at present building a flushing system driven by wave and tide oscillations that is designed specifically to clean up coastal lagoons (Alatorre-Mendieta et al. 2004). This system, expected to pump over $200 \mathrm{~m}^{3}$ $\mathrm{d}^{-1}$ of clean sea water to the lagoon at the inner end of the lagoon would decrease the residence time of water in the inner and central sectors of the lagoon to the same magnitude it has at present in the outer sector. If it works, this remedial action would also be a way of experimentally testing some of the ideas we have discussed here, particularly whether the two presently coexisting ecosystem states found in the lagoon will remain when the residence time is changed drastically.

In summary, the information gathered here allowed us to identify the eutrophication progression in the lagoon, where two different ecosystem states still coexist. This progression was outlined by a temporal decreasing trend in oxygen concentration loosely coupled to very significant increasing trends in TN and TP within the lagoon. UPGMA clustering and TI analyses were useful to detect spatial zonation due to differential physical and biogeochemical processes (mainly water exchange and nutrient loading), as well as the two ecosystem states (associated with main primary producers, interactions between organisms and trophic networks). In the near future the system will likely be exposed to 
changing conditions, on the one hand an increase in nutrient loads associated with tourism growth and on the other, hopefully, an intervention aimed at significantly decreasing the water residence time. These changes may allow the resilience of the two ecosystems that coexist there to be tested.

\section{REFERENCES}

Alatorre-Mendieta M., Silva-Casarín R., Ruiz-Renteria F., et al. 2004. A flushing system to clean up coastal lagoons. Coast. Struct. 2003: 902-910.

Camacho-Ibar V., Carriquiry J.D., Smith S. 2003. Non-conservative $\mathrm{P}$ and $\mathrm{N}$ fluxes and Net Ecosystem Production in San Quintín Bay, México. Estuaries 26: 1220-1237. https://doi.org/10.1007/BF02803626

Chagas G.G., Suzuki M.S. 2005. Seasonal hydrochemical variation in a tropical coastal lagoon (Acu lagoon, Brazil). Braz. J. Biol. 65: 597-607. https://doi.org/10.1590/S1519-69842005000400006

Ciglenečki I., Janeković I., Marguš M., et al. 2015. Impacts of extreme weather events on highly eutrophic marine ecosystem (Rogoznica Lake, Adriatic coast). Cont. Shelf Res. 108: 144-155. https://doi.org/10.1016/j.csr.2015.05.007

Cropp R., Gabric A. 2002. Ecosystem adaptation: Do ecosystems maximize resilience? Ecology 83: 2019-2026. https://doi.org/10.1890/0012-9658(2002)083[2019:EADEMR] 2.0. $\mathrm{CO} ; 2$

Dahloren S., Kautsky L. 2004. Can different vegetative states in shallow coastal bays of the Baltic Sea be linked to internal nutrient levels and external nutrient loads? Hydrobiologia 514: 249-258. https://doi.org/10.1023/B:hydr.0000018223.26997.b0

Expósito-Díaz G., Hernández-Albernas J., Gálvez-González W. 2001. Sondeo batimétrico de Laguna Larga (Cayo Coco). Center for Environmental Studies, Santa Clara, Cuba. 11 p.

Garcia-Pintado J., Martínez-Mena M., Barberá G.G., et al. 2007. Anthropogenic nutrient sources and loads from a Mediterranean catchment into a coastal lagoon: Mar Menor, Spain. Sci. Total Environ. 373: 220-239. https://doi.org/10.1016/j.scitotenv.2006.10.046

González A., Merino M., Czitrom S. 1992. Laguna Bojórquez, Cancún: un sistema de características marinas controlado por la atmósfera. An. Inst. Cienc. del Mar y Limnol. Univ. Nal. Auton. México, 19: 59-71

González-De Zayas R. 2012. Balance de nitrógeno y fósforo en una laguna costera tropical (Laguna Larga, Cayo Coco, Cuba). PhD dissertation, Univ. Nacional Autónoma de México, Mexico D. F., Mexico.

González-De Zayas R., Merino-Ibarra M., Soto-Jiménez M.F., et al. 2013. Biogeochemical responses to nutrient inputs in a Cuban coastal lagoon: runoff, anthropogenic, and groundwater sources. Environ. Monit. Assess. 185: 10101-10114. https://doi.org/10.1007/s10661-013-3316-y

Grasshoff K., Kremling K., Ehrhardt M. 1983. Methods of Seawater Analysis. Verlag Chemie, Weinheim.

Guimarais-Bermejo M., González-De Zayas R. 2011. Productividad primaria en Laguna Larga, Cayo Coco, Cuba. Rev. Cienc. Mar. Cost. 3: 31-41.

Hernández-Romero A.H., Tovilla-Hernández C., Malo E.A., et al. 2004. Water quality and presence of pesticides in a tropical coastal wetland in southern Mexico. Mar. Poll. Bull. 48: $1130-1141$. https://doi.org/10.1016/j.marpolbul.2004.01.003

Herrera-Silveira J.A. 2006. Lagunas Costeras de Yucatán (SE, México). Ecotróp. 19: 94-108.

Holling C.S. 1973. Resilience and stability of ecological systems. Ann. Rev. Ecol. Syst. 4: 1-23. https://doi.org/10.1146/annurev.es.04.110173.000245

Hrustić E, Bobanović-Ćolić S. 2017. Hypoxia in deep waters of moderately eutrophic marine lakes, Island of Mljet, eastern Adriatic Sea. Sci. Mar. 81: 431-447. https://doi.org/10.3989/scimar.04523.25A

Karydis M., Ignatiades L., Moschopoulou N. 1983. An index associated with nutrient eutrophication in the marine environment.
Est. Coast. Shelf Sci. 16: 339-344. https://doi.org/10.1016/0272-7714(83)90151-8

Kirkwood D. S. 1994. Sanplus segmented flow analyzer and its applications. Seawater analysis. Skalar, Amsterdam.

Kjerfve B. 1986. Comparative oceanography of coastal lagoons. In: Wolfe D. (ed.), Estuarine variability. Academic Press, Waltham, USA. pp. 63-81. https://doi.org/10.1016/B978-0-12-761890-6.50009-5

Kjerfve B. 1994. Coastal Lagoons. In: Kjerfve B. (ed.), Coastal Lagoon Processes. Elsevier. Amsterdam, Netherlands. pp. 1-8. https://doi.org/10.1016/S0422-9894(08)70006-0

Maler KG. 2000. Development, ecological resources and their management. A study of complex dynamic systems. Eur. Econ. Rev. 44: 645-665. https://doi.org/10.1016/S0014-2921(00)00043-X

Merino M., Czitrom S., Jordán E., et al. 1990. Hydrology and Rain Flushing of the Nichupté Lagoon System, Cancún, México. Est. Coast. Shelf Sci. 30: 223-237. https://doi.org/10.1016/0272-7714(90)90049-W

Merino M., González A., Reyes E., et al. 1992. Eutrophication in the lagoons of Cancún, México. Sci. Total Environ. 26: 861-870.

Morales-Ojeda S.M., Herrera-Silveira J.A., Montero J. 2010. Terrestrial and oceanic influence on spatial hydrochemistry and trophic status in subtropical marine near-shore waters. Water Res. 44: 5949-5964. https://doi.org/10.1016/j.watres.2010.07.046

Nixon S.W., Buckley B.A., Granger S.L., et al. 2001. Responses of very shallow marine ecosystems to nutrient enrichments. Hum. Ecol. Risk Assess. 7: 1457-1481. https://doi.org/10.1080/20018091095131

Olivera Y. 2014. Evaluación de la superposición de nichos en los ensambles de moluscos marinos de una laguna costera en Cayo Coco, Cuba. Master thesis. Centre for Marine Research, Havana Univ., Havana, Cuba.

Orfanidis S., Panayotidis P., Stamatis N. 2003. An insight to the ecological evaluation index (EEI). Ecolog. Indicat. 3: 27-33. https://doi.org/10.1016/S1470-160X(03)00008-6

Paerl H.W. 2006. Assessing and managing nutrient-enhanced eutrophication in estuarine and coastal waters: interactive effects of human and climatic perturbations. Ecolog. Engin. 26: 40-54.

Schramm W. 1999. Factors influencing seaweed responses to eutrophication: some results from EU-project EUMAC. J. Appl. Phycol. 11: 69-78. https://doi.org/10.1023/A:1008076026792

Schramm W., Nienhuis P. (eds). 1996. Marine benthic vegetation: Recent changes and the effects of eutrophication. Springer, Heidelberg, Germany. 470 pp. https://doi.org/10.1007/978-3-642-61398-2

Schröder A., Persson L., De Roos A.M. 2005. Direct experimental evidence for alternative stable states: a review. Oikos 110: 3-19. https://doi.org/10.1111/j.0030-1299.2005.13962.x

Souza M.F.L., Kjerfve B., Knoppers B., et al. 2003. Nutrient budgets and trophic state in a hypersaline coastal lagoon: Lagoa de Araruama, Brazil. Est. Coast. Shelf Sci. 57: 843-858 https://doi.org/10.1016/S0272-7714(02)00415-8

Tapia-González F.U., Herrera-Silveira J.A., Aguirre-Macedo M.L. 2008. Water quality variability and eutrophic trends in karstic tropical coastal lagoons of the Yucatán Peninsula. Est. Coast. Shelf Sci. 76: 418-430. https://doi.org/10.1016/j.ecss.2007.07.025

Taylor D.I., Nixon S.W., Granger S.L., et al. 1995. Responses of coastal lagoon plant communities to different forms of nutrient enrichment - a mesocosm experiment. Aquat. Botany 52: 19-34. https://doi.org/10.1016/0304-3770(95)00485-I

Valderrama J.C. 1981. The simultaneous analysis of total nitrogen and total phosphorus in natural waters. Mar. Chem. 10: 109-122. https://doi.org/10.1016/0304-4203(81)90027-X

Viaroli P. Bartoli M., Giordani G., et al. 2008. Community shifts, alternative stable states, biogeochemical controls and feedbacks in eutrophic coastal lagoons: a brief overview. Aquat. Conserv.: Mar. Freshw. Ecosyst. 18S1: S105-S117. https://doi.org/10.1002/agc.956

Wang B., Hu J., Li S. et al. 2017. A numerical analysis of biogeochemical controls with physical modulation on hypoxia during summer in the Pearl River estuary. Biogeosciences 14: 2979-2999. https://doi.org/10.5194/bg-14-2979-2017

Weiss R.F. 1970. Solubility of nitrogen, oxygen and argon in water and seawater. Deep-Sea Res. 17: 721-735. 